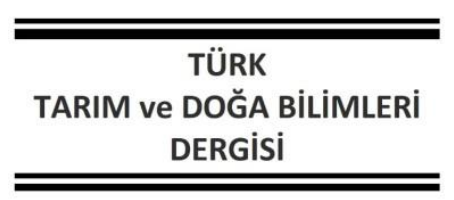

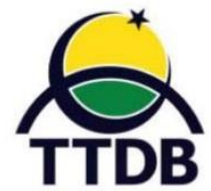

www.dergipark.gov.tr/turkjans

Araştırma Makalesi

\title{
Aktarlardaki Bitkisel Droglar ve Kullanımları: Isparta Örneği
}

\author{
Nimet KARA ${ }^{1 *}$, Halil ALINTAŞ², Bekir Sıtkı şiRikÇi², Mevlüt GÜL ${ }^{3}$ \\ ${ }^{1}$ Isparta Uygulamamalı Bilimler Üniversitesi, Ziraat Fakültesi, Tarla Bitkileri Bölümü, Isparta, Türkiye \\ ${ }^{2}$ Ziraat Mühendisi, Isparta, Türkiye \\ ${ }^{3}$ Isparta Uygulamamalı Bilimler Üniversitesi, Ziraat Fakültesi, Tarım Ekonomisi Bölümü, Isparta, Türkiye \\ *Sorumlu yazar: nimetkara@isparta.edu.tr
}

Geliş Tarihi: 12.12.2020 Düzeltme Geliş Tarihi: 07.06.2021 Kabul Tarihi: 29.06.2021

\section{Öz}

Araştırma, Isparta'da aktarlarda satılan ve halk arasında kulanılan bazı ilaç ve baharat bitkilerinin kullanım alışkanlıklarını incelenmek amacıyla yürütülmüştür. Veriler, toplam 16 aktar (15 erkek, 1 kadın) ve 200 tüketici ile yüz yüze görüşülerek elde edilmiştir. Elde edilen sonuçlara göre, en çok drog satın alımı yapan yaş grubunun 30 ile 45 arasında olduğu ve en yaygın sağlık probleminin diyabet ve tansiyon olduğu belirlenmiştir. Tüketicilerin \%42.5'i lise, \%35'i lisans, \%15.5’i ortaokul, \%5’i lisansüstü ve \%2'i ise ilköğretim mezunudur. Isparta'da aktarların 350'den fazla ürün çeşidine sahip oldukları, en fazla talep gören bitkilerin ise ıhlamur, adaçayı, kekik ve kuşburnu olduğu saptanmıştır. Aktarların \%75'i tüketicilere tedavi tavsiyesi vermediklerini ve \%25'i ise tedavi tavsiyesinde bulunduklarını beyan etmişlerdir. Tüketicilerin \%84'ünün alternatif tıp ile ilgili bilgilerinin olmadığı, bilgi sahibi olan tüketicilerin ise \%71.2 oranında internet ve televizyondan bilgi edindikleri belirlenmiştir. Araştırmada, bilinçli bir işletmecilik ve tüketim alışkanlığının olmadığı, tıbbi bitkiler ve ürünleri uzmanların önerileri doğrultusunda kullanılmalı, daha uygun koşullarda muhafaza edilmeleri ve son tüketim tarihlerinin yazılarak tüketiciye sunulması gerektiği soncuna varılmıştır.

Anahtar kelimeler: Bitkisel drog, aktar, ilaç ve baharat bitkileri.

\section{Herbal Drugs and Their Uses in Herbalist: The Case of Isparta}

\begin{abstract}
The research was conducted with aim to examine the usage habits of some medicines and spice plants used by the public and sold in herbalists in Isparta. The data were obtained through face-to-face interviews with a total of 16 herbalists (15 male, 1 female) and 200 consumers. According to the results, it was determined that the age group that the most drugs purchased are between 30 and 45 and the most common health problems are diabetes and blood pressure. $42.5 \%$ of the consumers are high school graduates, and their $35 \%$ are undergraduate, $15.5 \%$ are secondary school, $5 \%$ are graduate and $2 \%$ are primary education graduates. It has been determined that herbalists in Isparta have more than 350 kinds of products, and the most demanded plants are linden, sage, thyme and rosehip. $75.0 \%$ of herbalists stated that they did not give treatment advice to consumers and $25.0 \%$ of them recommended treatment. It is determined that $84 \%$ of the consumers did not have information about alternative medicine, and $71.2 \%$ of the consumers with knowledge was learned from the internet and television. In the research, there is no business management and consumption practice, medicinal plants and products should be used in according to the recommendations of experts and it was concluded that the drugs should be conserve at more suitable conditions and they should be presented to the consumer by writing the expiration dates.
\end{abstract}

Key words: Herbal drug, herbalist, medicinal and spice plants. 


\section{Giriş}

Tıbbi ve aromatik bitkiler asırlardan beri gıda, baharat, ilaç ve şifa vermesi yada şifa olması amacıyla kullanılmakta, günümüzde ise gıda, gıda katkıları, ilaç, kozmetik, parfümeri, baharat, içecek, boya, böcek öldürücü, antibiyotik, dekoratif gibi çok geniş bir alana hizmet etmektedirler. Türkiye farklı iklim özelliklerine sahip, 4080'i endemik (yalnızca bir bölgeye özgü tür) olmak üzere toplam 12476 bitki taksonu ile ılıman kuşaktaki en büyük doğal çeşitliliğe sahip ülkelerden biridir (Koyuncu ve ark., 2017).

Türkiye'de tıbbi ve aromatik bitkiler ağırlıklı olarak Ege, Marmara, Akdeniz, Doğu Karadeniz ve Güneydoğu Anadolu Bölgelerinden yabani olarak kontrolsüz bir şekilde toplanmaktadır. Ham veya yarı işlenmiş ürün olarak kullanılmaktadır. Türkiye coğrafi konumu, iklim ve bitki çeşitliliği, tarımsal potansiyeli, geniş yüzölçümü sayesinde tıbbi ve aromatik bitkiler ticaretinde önde gelen ülkelerden biridir. Türkiye'nin bu önemi; gelişmiş ülkelerdeki yerleşmiş bitkisel ilaç, bitki kimyasalları, gıda ve katkı maddeleri, kozmetik ve parfümeri sanayilerinin girdisini oluşturan pek çok bitkisel ürünü veren bitkilerin Türkiye florasında bulunmasından kaynaklanmaktadır.

İnsanlık tarihi boyunca birçok hastalık (şeker hastalığı, sarılık, nefes darlığı vb.) bitkiler kullanılarak tedavi edilmeye çalışılmış ve çalışılmaktadır. Dünya Sağlık Örgütü (WHO), dünyada yaklaşık 4 milyar insanın (dünya nüfusunun \%80'i) sağlık sorunlarını ilk etapta bitkisel droglarla gidermeye çalıştıklarını bildirmektedir. Ayrıca, gelişmiş ülkelerde reçeteli ilaçların yaklaşık \%25'ini bitkisel kökenli etken maddeler (vimbilastin, rezerpin, kinin, aspirin vb.) oluşturmaktadır (Farnsworth ve ark., 1985).

Illaçların yapımında kullanılan bitkisel, hayvansal ve madensel ilkel maddeleri (drog) satanlara aktar denir. Aktarlar çoğu zaman ilaç gibi kullanılan karışımları, alıcının şikayetine göre dükkanında kendi imkânlarıyla hazırladıkları gibi, kimi zaman da alıcı hammaddeyi aktardan alır ve kendisi yapar. Daha önceleri baharat sektörü ile uğraşanlar kokucular (koku, boyar madde ve baharat satma hakkına sahiptiler), aktarlar (eczaneler), baharatçılar ve kökçüler olarak sınıflandırılmışlardır. Aktarlık günümüzde daha çok baharatçılık adıyla sürdürülen bir meslek haline gelmiştir (Gürson ve ark., 2005; Çelik ve ark., 2019).

$\mathrm{Bu}$ çalışma, Isparta'da kullanılan tıbbi bitkilerin kullanım yöntemleri, mevsimlere göre tercih edilebilirlikleri, tüketici yaş aralığı, hangi hastalıklarda talebin fazla olduğu, genellikle hangi amaç için kullanıldıkları ve bitkisel tedavi yöntemlerinden ne derece faydalanıldığını saptamak ve bitkisel ürünlere yapılan harcama miktarlarını araştırmak amacıyla yürütülmüştür.

\section{Materyal ve Metot}

Araştırma, Isparta merkez aktarlarda halk arasında kulanılan bazı tıbbi ve aromatik bitkilerin kullanılan kısımları, kullanım şekli ve hangi amaçla kullanıldığını incelenmek için toplam 16 aktar (15 erkek, 1 kadın) ve 200 tüketici ile yüz yüze görüşülerek 2018 yılında yürütülmüştür. Daha önceden hazırlanan anket formunda, aktarlara ve tüketicilere yaş aralıkları, medeni durumu, eğitim durumları, işletme şekli, drogların kullanım durumları ve miktarları, tıbbi bitkileri hangi hastalık tedavisinde kullanma durumu, drogların tüketim sebepleri, drogları nereden temin ettikleri, drog fiyatları, tıbbi tedavi için ne kadar harcama yapıldığı, drogların dışında başka hangi tedavi yöntemlerinin kullanıldığı gibi sorular sorulmuştur. Aktar firma isimleri ve işletmeci isimlerine kendi istekleri doğrultusunda çalışmada yer verilmemiştir. Çalışmada aktarların bazı droglardan elde ettikleri kâr; ilgili drogların satış fiyatından, alış fiyatının çıkarılması ile saptanmıştır. Hesaplanan bu kârın satış fiyatına oranlanması ile de kâr marjı hesaplanmıştır. Bu hesaplamalarda: Kâr =Satış fiyatı - Alış fiyatı; Kâr marjı= (Satış fiyatı - Alış fiyatı)/Satış fiyatı formülleri kullanılmıştır. Anket sırasında aktarlar bitkilerin bilimsel isimlerini kullanırken, az sayıda bazı tüketiciler bitkilerin yerel ya da sinonim isimlerini kullanmışlardır. Fakat sunulan bu araştırmada tüm bitkilerin bilimsel isimleri kullanılmıştır.

\section{Bulgular}

\section{Aktarlardan elde edilen bulgular}

Isparta ilinde görüşülen aktarların 1'i kadın iken $15^{\prime}$ i erkektir. Görüşülen işletmecilerin aktarlık dışında herhangi bir iş ile uğraşmadıkları tespit edilmiştir. Görüşülen işletmecilerin herhangi bir tıbbi eğitimlerinin bulunmadığı ancak işletmelerin Tarım ve Orman Bakanlığı tarafından işyeri açma sertifikalarının olduğu, Tarım ve Orman Bakanlığı ve Sağlık Bakanlığı tarafından denetime tabi oldukları saptanmıştır. Görüşülen aktarlardan 9'u 30-45 yaş aralığında, 11'i evli, 10'u lise mezunudur. Isparta ilinde görüşülen aktarların 10'unun hukuki statüsü şahıs firması şeklinde $5^{\prime} i$ ortak, $1^{\prime} i$ ise şirket statüsündedir. Görüşülen aktarların 11'i ticaretini yaptıkları tıbbi bitkileri hastalık tedavisinde kullandıklarını belirtmişlerdir (Çizelge 1). 
Çizelge 1. Aktarlara (işletmeciler) ilişkin bazı bilgiler

\begin{tabular}{|c|c|c|c|c|c|}
\hline \multirow{3}{*}{ Yaş grupları } & $18-25$ & $25-30$ & $30-45$ & $45-65$ & \multirow{2}{*}{ Toplam } \\
\hline & \multicolumn{4}{|c|}{$\mathrm{N}$} & \\
\hline & 2 & 4 & 9 & 1 & 16 \\
\hline \multirow{3}{*}{ Medeni durum } & \multicolumn{4}{|c|}{ Bekar } & \\
\hline & \multicolumn{4}{|c|}{$\mathrm{N}$} & \\
\hline & 11 & & & & 16 \\
\hline \multirow{3}{*}{ Eğitim durumu } & Ortaokul & & Lise & Üniversite & \\
\hline & \multicolumn{4}{|c|}{$\mathrm{N}$} & \\
\hline & 1 & & 10 & 5 & 16 \\
\hline \multirow{3}{*}{ İşletme şekli } & Kendi & & Ortak & Şirket & \\
\hline & \multicolumn{4}{|c|}{$\mathrm{N}$} & \\
\hline & 10 & & 5 & 1 & 16 \\
\hline
\end{tabular}

İşletmeciler Isparta'da tüketicilerin drog satın alma sebeplerinin başında üst solunum yolu, kilo fazlalığı, eklem ağrıları ve diyabet hastalığının tedavisi olduğunu ifade etmişlerdir (Çizelge 2). İşletmecilerin $\% 75^{\prime} i$ tüketicilere tedavi tavsiyesi vermediklerini, \%25'i (4 işletmeci) ise tedavi tavsiyesinde bulunduklarını beyan etmişlerdir.

Çizelge 2. İşletmecilere göre drogların tüketim sebepleri

\begin{tabular}{ll}
\hline En çok tüketim sebebi & $\mathrm{N}^{*}$ \\
\hline Üst solunum yolları hastalıkları & 15 \\
Diyabet & 13 \\
Kilo fazlalığı & 15 \\
Eklem ağrıları & 15 \\
Depresyon & 3 \\
Tansiyon & 2 \\
\hline
\end{tabular}

*Birden fazla yanıt verilmiştir

İşletmecilerin Isparta ve çevresinden temin ettikleri droglardan başlıcaları; adaçayı, ıhlamur, kekik, papatya, kiraz sapı, nane, adaçayı, rezene, melisa, ekinezya, biberiye ve karabaşotudur. İthal yolla yurtdışından temin ettikleri droglar ise; damla sakızı, kahve, zencefil, tarçın, gingko, ginseng, hibisküs, safran, sarıkantaron ve yeşilçay'dır. İşletmeciler bu drogların büyük kısmının doğadan toplama yoluyla elde edilen ürünler olduğunu, daha az bir kısmının ise kültüre alınmış bitkiler olduğunu belirtmişlerdir.

Isparta ilinde tüketilen tıbbi ve aromatik bitkiler mevsime göre değişiklik göstermektedir. Yaz aylarında kahve, rezene, yeşilçay, melisa, hibisküs, kekik, narçiçeği, aleovera, tarçın, biberiye, papatya, çörekotu, kişniş, civanperçemi, defne yaprağı tercih edilmektedir. Kış aylarında ise; ıhlamur, adaçayı, rezene, kuşburnu, böğürtlen, zerdeçal, papatya, nane, kekik, tarçın, çörek otu ve sahlep daha çok satılmaktadır. İşletmelerin \%87.5'i damla sakızı, kahve, yeşilçay ve karabiber gibi bazı drogları temin etmekte zorluk çektiklerini belirtmişlerdir. İşletmelerin \%43.8'i 350'den fazla, $\% 25.2$ 'i 301-350 arası, \%18.8'i 100-200 arası, $\% 12.5^{\prime} i$ ise 250-300 arasında farklı drog çeşidine sahip olduklarını beyan etmişlerdir. İşletmecilerin $\% 50$ 'sinin tıbbi bitkiler dışında bitkisel ürün sattıkları bunlardan başlıcalarının ise; şampuan, sabun, krem, losyon gibi bitki özlü doğal kozmetik ürünlerin yanında kahve ve çeşitli baharatlar olduğu belirtilmiştir.

Aktarlarda satılan drogların \%56.3'ü 9-12 ay arasında, \%43.8'i ise 12 aydan daha fazla depolanmaktadır. Droglar poşet, cam kap, plastik kutular, kağıt kese ve çuval içerisinde muhafaza edilmektedir. Isparta'da aktarlarda en çok satılan drog aylık 16.9 kg ile ıhlamurdur. Ihlamuru 10.9 kg ile adaçayı, $8.1 \mathrm{~kg}$ ile kekik takip etmektedir (Şekil 1).

Aktarlar, en yüksek alış fiyatı 70.6 TL ile Gingko, 61.8 TL ile ıhlamur ve 54.3 TL ile kekik olduğunu ve satış fiyatları bakımından ise en yüksek değerin 93.1 TL ile ginkgo olduğunu beyan etmişlerdir. Hesaplanan alış ve satış fiyatlarına göre aktarların \%20'nin üzerinde bir marj ile satış yaptıkları belirlenmiştir. Marjın en yüksek olduğu drog \%25.4 ile ekinezya iken, en düşük \%20 ile kekik olduğu hesaplanmıştır (Çizelge 3). Aktarların elde ettikleri marjın \%20'nin üzerinde olmasının yanında paketleme, kira, sigorta vb. işletme masraflarının olduğu göz ardı edilmemelidir. 


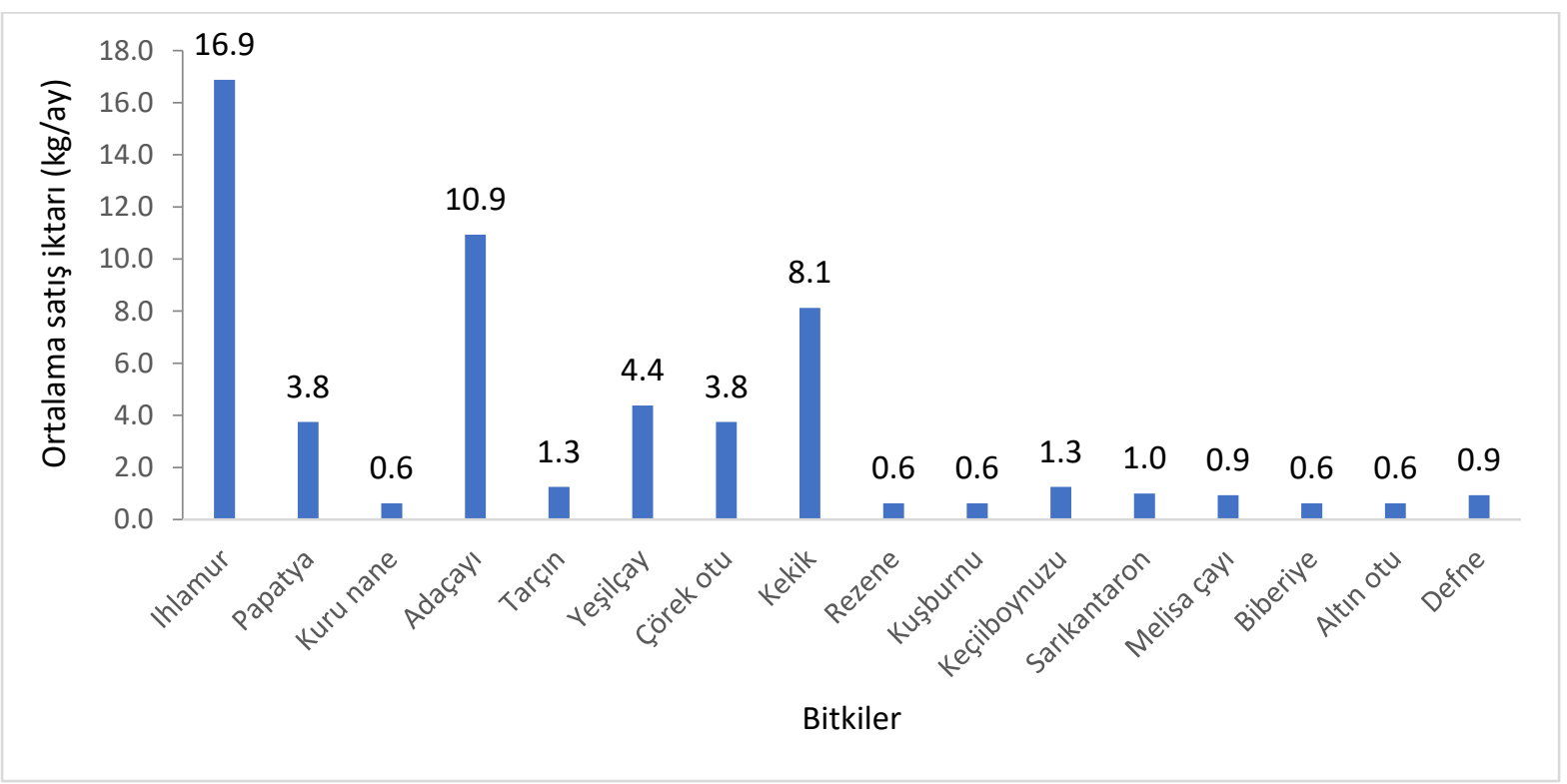

Şekil 1. Bazı droglara ortalama satış miktarları

Çizelge 3. Bazı droglara ilişkin alım-satım fiyatları

\begin{tabular}{lllll}
\hline Drog & Alış fiyatı $(\mathrm{TL} / \mathrm{kg})$ & Satış fiyatı $(\mathrm{TL} / \mathrm{kg})$ & Kâr $(\mathrm{TL})$ & Kâr marjı (\%) \\
\hline Ihlamur & 61.8 & 77.8 & 16.0 & 20.6 \\
Adaçayı & 47.9 & 62.1 & 14.1 & 22.8 \\
Melisa çayı & 34.3 & 43.6 & 9.3 & 21.4 \\
Ginkgo & 70.6 & 93.1 & 22.5 & 24.2 \\
Ekinezya & 28.4 & 38.1 & 9.7 & 25.4 \\
Sarı kantaron & 36.6 & 47.8 & 11.2 & 23.4 \\
Kekik & 54.3 & 67.8 & 13.6 & 20.0 \\
\hline
\end{tabular}

Tüketicilerden elde edilen bulgular

Araştırma bölgesinde 200 tüketici ile yüz yüze görüşme yapılmıştır. Elde edilen bulgulara göre, tüketicilerin \%32.5'i 31-45 yaş arasında, \%24'ü 25-30 yaş arasında, \%21'i 18-24, \%21'i ise $46-65$ yaş arasında \%1.5'i ise 65 yaş ve üzerindedir (Şekil 2).

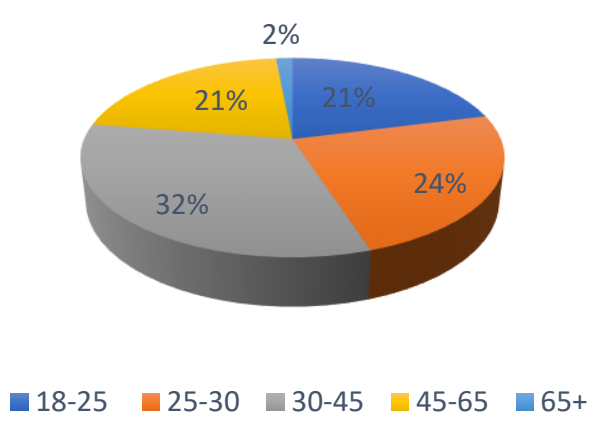

Şekil 2. Tüketicilerin yaş gruplarına göre dağılımı

Tüketicilerin \%42.5'i lise mezunu, \%35'i lisans mezunu, \%15.5'i ortaokul mezunu, \%5'i lisansüstü mezunu, \%2'i ise ilköğretim mezunudur (Şekil 3).

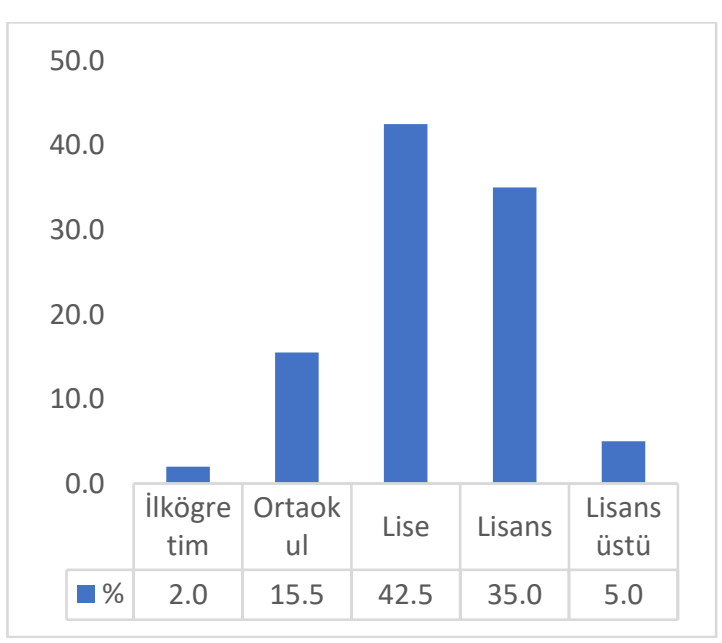

Şekil 3. Tüketicilerin eğitim durumlarına göre dağılımı

Tüketicilerin \%30'unun serbest çalışan, \%23'ünün öğrenci, \%12'sinin ev hanımı, \%11'inin emekli, \%4'ünün ise işçi olarak çalıştığı tespit edilmiştir (Çizelge 4). Görüşülen tüketicilerin \%60.5'inin hane büyüklüğünün, 2-3 kişiden, \%23.5'inin 4-5 kişiden, 
\%13.5'inin yalnız yaşadığı, \%2'sinin 5-6 kişiden oluştuğu belirlenmiştir.

Çizelge 4. Tüketicilerin çalışma durumu

\begin{tabular}{lll}
\hline Çalışma durumu & $\mathrm{N}$ & \\
\hline İşçi & 8 & 4.0 \\
Ev hanımı & 24 & 12.0 \\
Memur & 40 & 20.0 \\
Serbest çalışan & 60 & 30.0 \\
Emekli & 22 & 11.0 \\
Öğrenci & 46 & 23.0 \\
\hline Toplam & 200 & 100.0 \\
\hline
\end{tabular}

Tüketicilerin \%40.5'inin aylık hane gelirlerinin; 1501 TL ile 3000 TL arasında, \%36'sının 3001 TL ile 5000 TL arasında, \%14.5'inin 1001 TL ile 1500 TL arasında, \%8'inin 1000 TL'nin altında ve \%1'inin ise 5001 TL üzerinde olduğu belirlenmiştir (Çizelge 5).

Çizelge 5. Tüketicilerin gelir durumları

\begin{tabular}{lcc}
\hline Gelir (TL) & N & Oran (\%) \\
\hline 1000 ve altı & 16 & 8.0 \\
$1001-1500$ & 29 & 14.5 \\
$1501-3000$ & 81 & 40.5 \\
$3001-5000$ & 72 & 36.0 \\
5001 ve üzeri & 2 & 1.0 \\
\hline Toplam & 200 & 100.0 \\
\hline
\end{tabular}

Tüketicilerin \%57'si çeşitli sağlık problemleri olduğunu, \%43'ü ise herhangi bir rahatsızlıklarının olmadığını belirtmişlerdir. Görüşülen tüketiciler içerisinde en yaygın sağlık probleminin diyabet olduğu (\%18) saptanmıştır. Diyabeti \%17 oran ile tansiyon takip etmektedir. Diyabet ve tansiyon hastalığının yanında kalp, gastrit, obezite, ülseratif kolit, üst sonumum yolu enfeksiyonu, depresyon gibi sağlık problemlerine de görüşülen tüketicilerde rastlanılmıştır. Tüketicilerin \%84'ü alternatif tıp ile ilgili bilgilerinin olmadığını bildirmiştir. $\% 16^{\prime}$ sı ise alternatif tıp hakkında bilgilerinin olduğunu beyan etmişlerdir. Alternatif tıp hakkında bilgileri olduğunu beyan eden tüketicilerin bu bilgileri \%43.8 oranında internet, \%28.1 oranında televizyon, \%25 oranında yazılı kaynaklar, \%3.1 oranında ise aktarlardan elde ettikleri belirlenmiştir.

Araştırma bölgesinde görüşülen tüketicilerin tamamı karşılaştıkları sağlık problemlerine karşı tıbbi tedavi dışında yöntemler uyguladıklarını belirtmişlerdir. Tüketiciler (\%98.0) tıbbi tedaviler dışında en çok bitkisel yöntemleri uygularken, \%4.0'ı akapunkturu uyguladıklarını belirtmişlerdir (Çizelge 6). Doktor tavsiyesi üzerine uygulanan yöntemlerin ise kaplıca ve sülük tedavisi olduğu saptanmıştır.
Çizelge 6. Tüketicilerin tıbbi tedavi dışında uyguladıkları yöntemler

\begin{tabular}{lc}
\hline Yöntemler & Oran (\%)* \\
\hline Bitkisel yöntemler & 98.0 \\
Kaplıca & 66.0 \\
Kupa & 28.0 \\
Sülük tedavisi & 11.0 \\
Akapunktur & 4.0 \\
\hline *Birden fazla yanıt verilmiştir &
\end{tabular}

Tüketicilerin \%33'ü bitkisel droglara 11 TL ile 20 TL, \%32.5'i ise 21 TL ile 30 TL arasında, \%18'i 31 TL ile 50 TL arasında harcama yaparken, \%13'ü 10 TL'den az, \%3.5'i 50 TL'den daha fazla harcama yaptıklarını belirtmişlerdir (Çizelge 7).

Çizelge 7. Tüketicilerin bitkisel droglara aylık harcama tutarları

\begin{tabular}{lcc}
\hline $\begin{array}{l}\text { Harcama tutarı } \\
\text { (TL/ay) }\end{array}$ & $\mathrm{N}$ & Oran (\%) \\
\hline 10 TL altı & 26 & 13.0 \\
$11-20$ & 66 & 33.0 \\
$21-30$ & 65 & 32.5 \\
$31-50$ & 36 & 18.0 \\
50 TL üzeri & 7 & 3.5 \\
\hline Toplam & 200 & 100.0 \\
\end{tabular}

Tüketiciler bitkisel yöntemlerle modern tıp yöntemlerini karşılaştırdığında; tüketicilerin tamamı modern tıp yöntemlerini destekleyebilecek bir yöntem olduğunu ifade ederken, \%55'i ulaşılmasının veya bulunmasının modern tıp yöntemlerine nazaran daha kolay ve ucuz olduğunu, \%20.5'i bitkisel yöntemlerin daha zararsız olduğunu belirtmişlerdir. Görüşülen tüketicilerin \%93'ü bitkisel drogları tıbbi tedavi yöntemlerini desteklemek amacıyla satın aldıklarını, \%54'ü direkt tedavi amaçlı, \%17'si ise kozmetik amaçlı satın aldıklarını belirtmişlerdir. Tüketicilerin \%2.5'i satın aldıkları bitkisel drogların çeşitli yan etkileri olduğunu belirtmişlerdir. Bu yan etkilerin ise; ateş, bulantı, uyku hali olduğunu beyan etmişlerdir. Tüketicilerin \%81'i kullandıkları bitkisel drogları başkalarına tavsiye etmediklerini belirtmişlerdir.

Tüketicilerin \%96.5'i drogları aktarlardan satın aldıklarını, \%51'i semt pazarlarından, \%45.5'i doğadan kendilerinin topladıklarını, \%20'si marketlerden, $\% 19^{\prime} u$ ise internet üzerinden elektronik ticaret yolu ile satın aldıklarını belirtmişlerdir (Çizelge 8). 
Çizelge 8. Tüketicilerin satın alma kanalları

\begin{tabular}{lrr}
\hline Satın alma kanalı & $\mathrm{N}^{*}$ & Oran (\%) \\
\hline Aktar & 193 & 96.5 \\
Pazar & 102 & 51.0 \\
Doğadan & 91 & 45.5 \\
Market & 40 & 20.0 \\
İnternet & 38 & 19.0 \\
\hline
\end{tabular}

*Birden fazla yanıt verilmiştir

Tüketiciler tarafından en fazla talep gören bitkisel ürünün \%98.5 pay ile ıhlamur olduğu saptanmıştır (Çizelge 9). Ihlamuru sırası ile adaçayı kekik, kuşburnu takip etmektedir. Tüketiciler satın aldıkları bitkisel ürünleri niteliklerine göre; demleme, hap formunda, krem şeklinde, katı-sıvı karışım halinde, şurup şeklinde, toz halinde tükettiklerini belirtmişlerdir.

Çizelge 9. Tüketicilerin satın aldıkları bitkisel ürünler

\begin{tabular}{llc}
\hline Bitkisel ürünler & $\mathrm{N}^{*}$ & Oran (\%) \\
\hline Ihlamur & 197 & 98.5 \\
Adaçayı & 194 & 97.0 \\
Kekik & 155 & 77.5 \\
Kuşburnu & 125 & 62.5 \\
Papatya & 108 & 54.0 \\
Çörekotu & 100 & 50.0 \\
Rezene & 82 & 41.0 \\
Zencefil & 77 & 38.5 \\
Sarıkantaron & 75 & 37.5 \\
Ekinezya & 69 & 34.5 \\
Melisa & 63 & 31.5 \\
Gingko & 48 & 24.0 \\
\hline
\end{tabular}

*Birden fazla yanıt verilmiştir

\section{Tartışma}

Isparta ilinde aktar ve tüketiciler ile yapılan anket çalışmasında, işletmelerin genellikle şahıs firması olduğu, işletmecilerin ise herhangi bir tıbbi eğitimlerinin bulunmadığı ve eğitim durumlarının ağırlıklı olarak lise mezunu olduğu tespit edilmiştir. Isparta'da aktarların 350 dolayında ürün çeşidine sahip oldukları ve drogların büyük kısmının doğadan toplama yoluyla elde edildiği belirlenmiştir. Sarı ve ark. (2010) aktarlarda kullanılan bitkilerin \%74'nün doğadan toplama yolu ile elde edildiğini bildirmişlerdir. Erdemir (1998) tedavi amacıyla kullanılan ilaç ve baharat bitki sayısının 500 civarında olduğunu ve bu sayının her geçen gün arttığını, Ötnü ve Akan (2020) Şanlıurfa'da 144 bitkinin fitoterapi amaçlı satıldığını, Bozdoğangil (1996), Çukurova Bölgesinde ilaç ve çeşitli amaçlarla 244 bitkinin kullanıldığını bildirmişlerdir.
Drogların genellikle doğal ortamlarda muhafaza edildiği belirlenmiş, bu durum hijyenik sorunların ortaya çıkabileceğini göstermektedir.

Bitkisel drogları kullanan tüketicilerin yarıya yakının çeşitli sağlık problemlerinin olduğu, satın alma sebeplerinin başında üst solunum yolu, kilo fazlalı̆̆ı, eklem ağrıları ve diyabet hastalığının geldiği ve en çok satılan drogların ıhlamur, adaçayı ve kekik olduğu belirlenmiştir. Vehbi (2014) drogların mevsim dönümlerinde sıklıkla görülen üst solunum yolu enfeksiyonlarında kullanıldığını ve KKTC'de en çok satılan ürünlerin adaçayı, zencefil, hatmi ve ıhlamur olduğunu bildirmiştir. Özgen ve ark. (2012) Erzurum'da yürüttükleri bir araştırmada; 70 bitki türünün, romatizma, deri hastalıkları, solunum hastalıkları, mide rahatsızlıkları, enfeksiyonlar ve hemoroit gibi rahatsızlıklarda kullanıldığını bildirmişlerdir. Ozan (2011) aktarlarda satılan drogların en sık kullanım amacının bağırsak hastalıkları, gastrit, gaz söktürücü, hazımsızlık, hemoroit, ishal, iştah açıcı, kabızlık, spazm, ülser, astım, bronşit, grip, nezle, öksürük, soğuk algınlığı olduğunu bildirmiştir.

Bitkisel droglar belirli bir zümre tarafından değil, her meslek grubu tarafından kullanılmaktadır. Toplumda bilinenin aksine tüketicilerin okuryazar oranının yüksek olduğu (\%23'ü öğrenci) belirlenmiştir. Sarı ve ark. (2010) tüketicilerin \%95 inin okuryazar olduğu okur-yazar olmayanların oranı ise $\% 5$ olduğunu bildirmişlerdir. $\mathrm{Bu}$ durum bize tüketicilerin bilinçli kullanım oranının yüksek olduğunu göstermektedir.

Tüketicilerin çok büyük bir kısmı alternatif tıp ile ilgili bilgilerinin olmadığını ve karşılaştıkları sağlık problemlerine karşı tıbbi tedavi dışında yöntemler de uyguladıklarını ifade etmişlerdir. Bilgi sahibi olan az sayıdaki tüketicilerin bilgi kaynağının güvenilir olmadığı (internet, televizyon) belirlenmiştir. Tulukcu ve Sağdıç (2011) aktarlarda satılan bitkilerin genellikle, özensiz bir şekilde toplandığı, satış ve kullanım için yeterli bilgiye sahip olunmadığını bildirmişlerdir. Aktürk ve ark. (2006) Türkiye'de alternatif ve destekleyici tedavilere ilginin giderek artmakta olduğunu ve hastaların alternatif kaynakları kullanma oranının \%30-70 arasında olduğunu bildirmişlerdir. Nicholson (2006) drogları kullanan birçok insanın hastalıklarını tedavi etmek için değil, hastalıklara karşı önlem almak ve iyileşme sürecini hızlandırmak için kullandıklarını bildirmiştir.

\section{Sonuç ve Öneriler}

Araştırma soncuna göre, Isparta'daki aktarcılığın babadan oğula geçen bir meslek olduğu ve konuyla ilgili herhangi bir eğitim alınmadığı belirlenmiştir. En çok alışveriş yapan tüketicilerin orta yaş (30-45 yaş) grubunda olduğu ve \%84'ü 
alternatif tıp ile ilgili bilgilerinin olmadığını, ancak bitkisel drogların modern tıp yöntemlerini destekleyebilecek bir yöntem olduğunu ifade etmişlerdir.

Tüketicilerin çok büyük bir bölümünün düşük gelire sahip olduğu ve \%96.5'nin drogları aktarlardan satın aldıkları saptanmıştır. Tüketiciler, drogların modern tıp yöntemlerine nazaran daha ucuz zararsız olduğuna inanmaktadırlar. Bunun yanında tüketicilerin $\% 81^{\prime} i$ kullandıkları bitkisel drogları başkalarına önermediklerini belirtmişlerdir.

Aktarlar en çok kış mevsiminde satış yaptıklarını (\%98.5 pay ile ıhlamur ilk sırada yer almaktadır) ve tüketiciler drog satın alma sebeplerini en fazla soğuk algınlığı, üst solunum yolu hastalıkları ve diyabet hastalığının tedavisi olarak sıralamışlardır. Tüketiciler satın aldıkları bitkisel ürünleri demleme, katı-sıvı karışım halinde, şurup şeklinde ve toz halinde tükettiklerini belirtmişlerdir.

Sonuç olarak, tüketicilerin bir bölümü drogların hastalıklara karşı önleyici bir tedbir olarak kullandıklarını belirtseler de, bir bölümünün bir ilaç gibi kullandıkları görülmektedir. Bilinçli bir kullanım için uzmanların önerilileri dikkate alınmalı ve aktarlar tüketicilere öneride bulunmamalıdır. Ayrıca, droglar aktarlarda daha uygun koşullarda muhafaza edilmeli ve son tüketim tarihleri yazılarak tüketiciye sunulması önerilmektedir.

Çıkar Çatışması Beyanı: Makale yazarları aralarında herhangi bir çıkar çatışması olmadığını beyan ederler.

Araştırmacıların Katkı Oranı Beyan Özeti: Araştırmada anket çalışması N.K ve H.A tarafından, istatik analizi B.S.Ş ve M.G tarafından yapılmıştır. Yazarlar makalenin metin kısmına eşit oranda katkı sağlamış olduklarını beyan ederler.

\section{Kaynaklar}

Aktürk, Z., Dağdeviren, N., Yıldırım, T., Yılmazer, A.Z., Bulut, F.G. ve Subaşı, B. 2006. Tıp öğrencileri bitkileri ne kadar tanıyor? Tıp Fakültesi birinci ve altıncı sınıf öğrencileri arasında bitkilerin ve sağııktaki kullanım alanlarının bilinme durumu. Genel Tıp Dergisi, 16(3): 101-106.

Bozdoğangil, E.E. 1996. Çukurova Bölgesinde Doğal Olarak Bulunan Faydalı Bitkiler ve Kültür Olanakları Üzerinde Araştırmalar. Çukurova Üniversitesi Fen Bilimleri Enstitüsü Tarla Bitkileri Anabilim Dalı Yüksek Lisans Tezi, Adana.

Çelik, T.A., Şentürk, M. ve Aslantürk, Ö.S. 2019. Aydın il merkezinde faaliyet gösteren aktarların kişisel ve mesleki özelliklerinin belirlenmesi. Ordu Üniversitesi Bilim ve Teknik Dergisi, 9(2): 126-135.

Erdemir D.A. 1998. At Kestanesi (ve Prepagel) Doğanın Harika ilacı. Nobel Kitap Evi İstanbul, 1998.

Farnsworth, N.R., Akerele, O., Bingel, A.S., Soejarto, D.D. ve Guo, Z.G. 1985. Medicinal Plants in Therapy. Bulletion, WHO 63: 965981.

Gürson, O, Özçelikay, G. ve Asil, E. 2005. A study on medicinal herb trading applications in Ankara. Journal of Medical Ethics, 13: 191194

Koyuncu, O., Kocaman, B.G., Yaylacı, Ö.K., Özgişi, K., Sezer, O. ve Erkara, i.P., 2017. The vascular plant flora of Pazaryeri (Bilecik) and environs. Artvin Çoruh Üniversitesi Orman Fakültesi Dergisi, 18(1): 36-50.

Nicholson, T. 2006. Complementary and alternative medicines (Including Traditional Māori Treatments) used by presenters to an emergency department in New Zealand: A survey of prevalence and toxicity. Journal of the New Zealand Medical Association, 119: 12-33.

Ötnü, H. ve Aka, H. 2020. Şanlıurfa'daki eczanelerde ve aktarlarda fitoterapi amaçlı satılan bitkiler. KSÜ Tarım ve Doğa Dergisi, 23(4): 947-965.

Özgen, U., Kaya, Y. ve Houghton, P. 2012. Folk medicines in the villages of Ilıca District (Erzurum, Turkey). Turkish Journal Biology, 36: 93-106.

Tulukcu, E. ve Sağdıç, O. 2011. Konya'da aktarlarda satılan tıbbi bitkiler ve kullanılan kısımları. Erciyes Üniversitesi Fen Bilimleri Enstitüsü Dergisi, 27(4): 304-308.

Vehbi, V. 2014. K.K.T.C.'de Aktarlarda satılan tıbbi bitkiler ve kullanılan kısımları. Yakın Doğu Üniversitesi Sağlık Bilimleri Enstitüsü, Farmasotik Botanik Yüksek Lisans Tezi, 77s. 